\title{
Interest of People in News Relate with their Blood Grouping
}

\section{Qadir MI and Adnan M*}

Institute of Molecular Biology and Biotechnology, Bahauddin Zakariya University, Pakistan

*Corresponding author: Muhammad Adnan, Institute of Molecular Biology and Biotechnology, Bahauddin Zakariya University, Multan, Pakistan,Email: ak544755@gmail.com

\section{Research Article}

Volume 3 Issue 2

Received Date: December 11, 2018

Published Date: December 21, 2018

DOI: $10.23880 /$ oajmb-16000133

\section{Abstract}

Objective of present study was co-related blood grouping with news lover we were performed an experiment to determine the blood group, then we asked them that they like to listening news or not. All the students answer the question in their related blood group box.179 was total students who answer the question. .with the help of this project we were able to know the views of students about news.

Keywords: Blood grouping; News lover; BZU students

\section{Introduction}

The blood grouping is an important phenomenon of our body. There are three types of blood groups A and B and $O$ these three blood groups again divided into two parts, one is negative and other is positive. Blood group A contain antigen A and antibodies against B Blood group B contain antibodies against $A$ and vice versa. Blood group $O$ contains no antigen but both $\mathrm{A}$ and $\mathrm{B}$ antibodies on serum. All the process of antiserum and antibodies are worked on red blood cells. Which play an important role in our body [1].

RH factor also has its own importance. The antiserum $\mathrm{D}$ indicates the presence of $\mathrm{Rh}$ factor. $\mathrm{Rh}$ factor indicate the blood as positive or negative If the antiserum $\mathrm{D}$ coagulate with blood on slide A or B it means that Rh factor is present and the blood group is positive the absence of $\mathrm{Rh}$ factor indicate that the blood is negative [2]. News is very important in society due to much reason. Its main aspect is to inform the people that what is happened around them. News also provides entertainment' News also causes to connect people and their events with each other. News is important as it gather many social people too; Newspaper plays an important role in the field of news. Where there a lot of people get chance to connected with each other. Some peoples like news but some not, because now a days newspapers and channels involved in a bad impact. Political interference play a bad role in news agencies, it is very hard to find the neutral news. This is the reason that people like or dislike the news.

Objective of present study was co-relate blood grouping with news lover

\section{Materials and Methods}

\section{Blood grouping}

We performed an experiment to determine the blood group .We took three slides and marks it as A, B and D. We took three sample of my body blood marked as A B and D we put antisera $A$ on slide $A$, antisera $B$ on slide $B$, and out antisera $\mathrm{D}$ on the slide $\mathrm{D}$. We start to mix antlers with blood antisera D determine the presence of $\mathrm{RH}$ factor which confirmed the blood group as positive or negative. 


\section{Open Access Journal of Microbiology \& Biotechnology}

Only the sample D broke down through which we know that my Blood group was $\mathrm{O}+$.

\section{Project}

A questioner was prepared about, you like to listening news? We took blood sample of all and checked their blood group, then we asked them that they like to listening news or not. All students give answer according their blood group in their related blood group box. Results also will be calculated after completion of project.

\section{Statistical Analysis}

Statistical analyses were performed by using Microsoft world.

\section{Result and Discussion}

179 total students take part in project by giving answers of the question in their related blood group box. The numbers of all students male and female according to their blood group are as 31 students were related to $\mathrm{A}^{+} 10$ boys and 20 girls blood group and only 2 students 1 boy and 1 girl were A-blood group. 60 students mostly girls have $\mathrm{B}^{+} 8$ boys and 52 girls. Only 6 students were having B-blood group in which 3 boys and 3 girls were present. Similarly 11 students having blood group $\mathrm{AB}^{+}$asked the same question in which 3 was boys and 8 were girls .only one girl from all 179 students was having $\mathrm{AB}^{-}$blood group. $\mathrm{O}^{+}$related to 57 students who answer the question in which 17 were boys and 40 girls present. Only 11 students related to blood group 0-10 girls and only 1 boy. The result given in the percentage form in the Table 1.

\begin{tabular}{|c|c|c|c|c|}
\hline \multirow{2}{*}{} & \multicolumn{2}{|c|}{ Yes } & \multicolumn{2}{c|}{ NO } \\
\cline { 2 - 5 } & Male & Female & Male & Female \\
\hline A+ & $90.90 \%$ & $55 \%$ & $9.09 \%$ & $45 \%$ \\
\hline A- & $100 \%$ & $100 \%$ & $0.00 \%$ & $0.00 \%$ \\
\hline B+ & $75 \%$ & $59.61 \%$ & $25 \%$ & $40.39 \%$ \\
\hline B- & $100 \%$ & $66.66 \%$ & $0 \%$ & $33.33 \%$ \\
\hline AB+ & $100 \%$ & $62.50 \%$ & $0 \%$ & $37.35 \%$ \\
\hline AB- & $0 \%$ & $0 \%$ & $0 \%$ & $100 \%$ \\
\hline O+ $^{+}$ & $88.23 \%$ & $52.50 \%$ & $11.77 \%$ & $47.50 \%$ \\
\hline $\mathbf{0}^{-}$ & $100 \%$ & $70 \%$ & $0 \%$ & $30 \%$ \\
\hline
\end{tabular}

Table 1: Questionnaire based studies

Questionnaire based studies have been given important outcomes in current researches. No one perform the same project before [3-10].

\section{Conclusion}

It was concluded from the present study that the people related with blood group $\mathrm{A}^{+}$and $\mathrm{O}^{+}$has maximum interest in news, while $\mathrm{B}^{+}$and $\mathrm{AB}^{+}$have the mix situation and other blood groups have about less than half peoples who like to listening news .with the help of this project I was able to know the views of students about news.

\section{References}

1. Qadir MI, Malik SA (2010) Comparison of alterations in red blood cell count and alterations in hemoglobin concentration in patients suffering from rectal carcinoma undergoing 5-fluorouracil and folic acid therapy. Pharmacologyonline 3: 240-243.

2. Qadir MI, Noor A (2018) Anemias. Rare \& Uncommon Diseases. Cambridge Scholars Publishing. Newcastle, England.

3. Qadir MI, Javid A (2018) Awareness about Crohn's Disease in biotechnology students. Glo Adv Res J Med Medical Sci 7(3): 62-64.

4. Qadir MI, Saleem A (2018) Awareness about ischemic heart disease in university biotechnology students. Glo Adv Res J Med Medical Sci 7(3): 59-61.

5. Qadir MI, Ishfaq S (2018) Awareness about hypertension in biology students. Int J Mod Pharma Res 7(2): 8-10.

6. Qadir MI, Mehwish (2018) Awareness about psoriasis disease. Int J Mod Pharma Res 7(2): 17-18.

7. Qadir MI, Shahzad R (2018) Awareness about obesity in postgraduate students of biotechnology. Int J Mod Pharma Res 7(2): 14-16.

8. Qadir MI, Rizvi M (2018) Awareness about thalassemia in post graduate students. MOJ Lymphology \& Phlebology 2(1): 14-16.

9. Qadir MI, Ghalia BA (2018) Awareness survey about colorectal cancer in students of M. Phil Biotechnology at Bahauddin Zakariya University, Multan, Pakistan. Nov Appro in Can Study 1(3): NACS.000514.2018.

10. Qadir MI, Saba G (2018) Awareness about intestinal cancer in university student. Nov Appro in Can Study 1(3): NACS.000515.2018. 